\title{
PAHAM INGKAR SUNAH DI INDONESIA (STUDI TENTANG PEMIKIRANNYA)
}

\author{
Abdul Majid Khon \\ UIN Syarif Hidayatullah Jakarta \\ abdulmajidkhon@yahoo.com
}

\begin{abstract}
Paham Ingkar Sunah Indonesia timbul dari ketidak tahuannya tentang status Sunah dalam beragama dan tentang fungsi Sunah terhadap al-Qur'an. Semangat belajar mereka hanya pada al-Qur'an. Tetapi sayangnya mereka sangat minim penguasaan ilmu-ilmu dasar untuk memahami al-Qur'an seperti bahasa Arab, tata bahasa dan sastranya, ilmu-ilmu Tafsir dan lain-lain. Mayoritas ide-ide penolakan Sunah ditransfer dari orientalis yang sengaja menghembuskan di dunia Islam untuk menyesatkan umat. Inti pandangan mereka bahwa dalam beragama hanyalah al-Qur'an karena kesempurnaannya sedangkan Sunah atau hadis dipandang sebagai dongeng yang diciptakan oleh sebagian umat Islam belakangan. Mengikuti Hadis mimicu perpecahan umat yang meneybabkan kelemahan dan kehancuran umat.
\end{abstract}

Kata Kunci: inkar sunnah, Indonesia, ilmu-ilmu tafsir, nabi.

\section{PENDAHULUAN}

Paham Ingkar Sunah muncul di Indonesia secara terang-terangan kirakira terjadi pada tahun 1980-an. Persisnya menurut Zufran Rahman (seorang peneliti pemikiran Ingkar Sunah dan Dosen IAIN Jambi) pada tahun 1982-1983. ${ }^{1}$ Tetapi bukti menunjukkan, bahwa pada 1981 paham ini sudah ada seperti yang terjadi di Bogor pimpinan oleh H. Endi Suradi dan 1982 aliran sesat yang diajarkan H. Sanwani asal kelahiran Pasar Rumput itu sudah berlangsung sejak November 1982. ${ }^{2}$ Kemungkinan besar jauh sebelum itu sudah ada penyebarannya secara sembunyi-sembunyi seperti yang dilakukan oleh orientalis di Indonesia Snouck Hourgronje. Buku-buku orientalis atau kaki tangannya sudah bertebaran jauh sebelumnya.

Indonesia memang menjadi sasaran gerakan modern Ingkar Sunah 
setelah India dan Mesir. Dalam sejarah penetesan Ingkar Sunah era modern di India dalam rangka melemahkan semangat jihad umat Islam dan menghancurkan Islam dari dalam melalui ide-ide kaum emperealis Inggris bekerja sama dengan para tokoh-tokoh Islam India yang koperatif. Kemudian dikembangkan lagi melalui pemikiran orientalis yang bertebaran di Mesir, karena mereka tahu benar bahwa Mesir adalah pusat informasi dunia Islam baik bagi yang berkedok research ilmiah yang dituangkan ke dalam buku-buku mereka maupun berhadapan langsung dengan para mahasiswa maupun dosennya melalui pengajaran di al-Azhar Mesir. Gerakan pemikiran modern Ingkar Sunah di Indonesia menjadi target mereka setelah Mesir, karena Indonesia berpenduduk mayoritas Islam terbanyak di seluruh dunia Islam.

Sekitar tahun 1980-an paham pemikiran modem Ingkar Sunah Indonesia bergerak di beberapa tempat dan pada tahun 1983-1985 mengcapai puncaknya sehingga menghebohkan masyarakat Islam dan memenuhi halaman berbagai harian koran dan majalah. Pusat pergerakan mereka di Jakarta yang mendominasi jumlah pembawanya yang mayoritas, kemudian di Bogor Jawa Barat, Tegal Jawa Tengah dan Padang Sumatra Barat.

Penyebaran paham pemikiran modern Ingkar Sunah melalui berbagai cara di antaranya ada yang melalui pengajian di beberapa Masjid, diktat tulisan tangan, ceramah melalui kaset, dan buku. Banyak di antara umat Islam yang terbawa dan terpengaruh pemahaman tersebut baik sebagai tokoh, pembantu dan pengikut. Di antaranya; Lukman Saad (Dirut PT Ghalia Indonesia), Mawardi Saad, Edria Zamora, Boni Alamsyah (ketiganya karyawan PT Ghalia Indonesia), Ansor W.A. Gani, Husni Nasution, Imran Nasution, Ali Sarwani Basry, Zainal Arifin, Muhammad Umar (Sekretaris BPMI), Dadang Satiogroho (karyawan Unilever Bogor), Selamet Sumedi (Grogol), Teguh Esha (Cipete Dalam), Dahlan (Sawangan Depok), Uas dan istrinya (Sawangan Depok), Rohadi (Pondok Cina), H. Abdurrahman (Parung), Mahmud (manantu Abdurrahman, Kebembem), H. Abdullah (Cileduk), H. Sanwani (Pasar Rumput), Safran Batu Bara (Guru SMP Yayasan Waqaf Muslim Tanah Tinggi), Manirus Taka (Indo-Jerman tinggal Depok Timur), Ishak Saleh (Cirebon), Dalimi Lubis (Sumatra Barat), ${ }^{3}$ Nazwar Syamsu (Sumatra Barat), As'ad bin Ali Baisa (usia 60 tahun di Tegal Jawa Tengah) ${ }^{4}$ dan H. Endi Suradi (Bogor Jawa Barat).

Paham Ingkar Sunah di Indonesia terlarang beredar dengan terbitnya Keputusan Mahkamah Agung RI No: KEP-169/J.A/9/1983 dan Nomor: KEP-059/J.A/3/1984. Namun, paham ini masih tetap eksis pada masa berikutnya sampai sekarang. Terkadang masih muncul paham ini secara sembunyi di berbagai media, baik buku, Koran, bulitin dan lain-lain. Agar 
pemikirannya dapat ditelaah dengan baik, artilkel yang singkat ini akan membahas; siapa Ingkar Sunah di Indonesia? Bagaimana pemikirannya? Bagaimana tingkat keingkaran mereka terhadap Sunah?. Berikut ini akan dipaparkan secara singkat di antara tokoh Ingkar Sunah Indonesia dan pemikirannya yang sangat menonjol dan berperan penting dalam sejarah.

\section{TOKOH-TOKOH INGKAR SUNAH DAN PEMIKIRANNYA}

\section{Ir. M Ircham Sutarto}

Ir. M. Ircham Sutarto adalah Ketua Serikat Buruh Perusahaan Unilever Indonesia di Cibubur Jawa Barat. Menurut Hartono Ahmad Jaiz (Peneliti Ingkar Sunah) dialah tokoh Ingkar Sunah dan orang pertama yang menulis diktat dengan tulisan tangan. ${ }^{5}$ Ircham Sutarto mempunyai peran yang sangat besar dalam penyebaran paham Ingkar Sunah di Indonesia, karena ia sebagai Ketua Serikat Buruh perusahaan Unilever milik orang Belanda. Sementara itu Lukman Saad seorang Direktur PT Ghalia Indonesia yang bergerak di bidang penerbitan dalam perkembangan berikutnya mendapatkan mesin percetakan modern untuk mencetak buku-buku Ingkar Sunah setelah kepergiannya ke negeri Belanda dan bolak balik ke sana. Lukman Saad berasal dari Padang Panjang Sumatra Barat, alumni IAIN Sunan Kalijaga sampai Sarjana Muda yang mendapat gelar BA pada waktu itu. ${ }^{6}$

Diktat tulisan Ir Ircham Sutarto tersebut belum diberi judul karena nampaknya masih dalam penyelesaiaan dan diktat inilah yang dijadikan pegangan dalam mengajar dan ceramah. Isinya tentang agama (dîn), taat kepada Allah dan kepada Rasul. Dasar pembahasannya hanya menggunakan dalil-dalil al-Qur'an sedang dalil selain al-Qur'an ditolak termasuk Sunah. Tetapi baik disadari atau tidak, di samping ia tidak sepenuhnya meninggalkan Sunah, ia lebih cenderung menggunakan dalil akli atau pikirannya. Ketika ia berbicara dengan lawan bicaranya dan mendengar dalil Sunah langsung menolak dan menutup telinga dengan tangannya. ${ }^{7}$

Di antara ajarannya yang dimuat dalam Diktat dan dikutip oleh Ahmad Husnan adalah sebagai berikut:

a. Taat kepada Allah, Allah itu ghaib. Taat kepada Rasul, Rasulpun telah wafat. Jadi tidak ada jalan kedua-duanya untuk melaksanakan taat dengan arti yang sebenarnya (M Ircham Sutarto: 85).

b. Allah telah mengajarkan al-Qur'an kepada Rasul. Rasul telah mengajarkan al-Qur'an kepada manusia. Al-Qur'an satu-satunya yang masih ada. Allah dan Rasul-Nya menunggal dalam ajaran agama ( H Ircham Sutarto: $82 \&$ 85).

c. Al-Qur'an adalah omongan Allah dan omongan Rasul. Itulah arti 
taat kepada Allah dan kepada Rasul (M Ircham Sutarto: 52 \& 85)

d. Keterangan al-Qur'an itu ada di dalam al-Qur'an itu sendiri. Jadi tidak perlu dengan keterangan yang disebut al-sunah atau hadis (M Ircham Sutarto: 58)

e. Semua keterangan yang datang dari luar al-Qur'an adalah hawa. Jadi hadis Nabipun termasuk hawa. Karena itu tidak dapat diterima sebagai hujah dalam agama (M Ircham Sutarto: 22)

f. Apa yang disebut Hadis-hadis Nabi itu tidak lain hanya dongengdongeng tentang Nabi yang didapat dari mulut ke mulut. Timbulnya dari gagasan orang-orang yang hidup antara tahun 180 sampai dengan 200 setelah wafatnya Rasul ( M Ircham Sutarto: 68 \& 70)

g. Rasul tidak ada hak mengenai urusan perintah agama. Olehnya dibawakan ayat QS Ali Imran/3: 128:

"Tidaklah ada (haq) wewenang bagi kamu tentang urusan (perintah) sedikitpun". (terjemahan M Ircham Sutarto)

h. Perbedaan Muhammad sebagai Rasul dan Muhammad sebagai manusia; Apabila Muhammad menyampaikan, membacakan mengajarkan al-Qur'an dan hikmah, di saat itu Muhammad sebagai Rasul. Sedang apabila tidak demikian, dalam arti Muhammad sedang melakukan segala sesuatu dalam kehidupan sehari-hari dengan segala fi'il dan qaulnya, di saat itu Muhammad sebagai manusia biasa. (M Ircham Sutarto : 94)

i. Semua manusia telah tersesat sebelum mendapat wahyu, termasuk Muhammad saw. Dalilnya QS. Al-Baqarah/2: 198

Dan ingatlah kepadanya seperti yang telah kami tunjukkan kepadamu dan sesungguhnya kamu (Muhammad) sebelumnya benar-benar orang tersesat. (terjemahan M Ircham Sutarto: 15 \& 16)

j. Di dalam agama, perbuatan lahiriah merupakan pelengkap batiniah atau iman (M Ircham Sutarto: 51$)^{8}$

\section{Abdurrahman}

Abdurrahman tinggal di Pedurenan, Kuningan, Jakarta. Seorang mantan Persis (Persatuan Islam) berusia 30 tahun pada tahun 1983. ${ }^{9}$ Dia giat mengajar dan ceramah di beberapa tempat sekitar Jakarta dan jamaahnya di antar dan dijemput dengan kendaraan mobil. Beberapa masjid di Jakarta ia kuasai salah satu di antaranya Masjid Asy-Syifa di Rumah Sakit Pusat Cipto Mangunkusumo. Salah satu Rumah Sakit yang menyatu dengan Universitas Indonesia dan menjadi tempat praktek Fakultas Kedokteran. 
Pengajian dimulai setelah shalat Maghrib sampai dengan waktu Isya tiba. Di antara ajarannya:

a. Tidak ada dzan dan tidak ada iqamat pada saat akan menjalankan shalat wajib dengan alasan tidak ada perintah dalam al-Qur'an.

b. Masing-masing salat lima waktu hanya dilakukan dua rakaat. ${ }^{10}$

Senada dengan pengajaran Abdurrahman Ust. H. Sanwani yang berasal dari Pasar Rumput Jakarta pernah aktif di NU tetapi kemudian menyebrang ke paham Ingkar Sunah. ${ }^{11}$ Dia seorang guru masyarakat setempat dan mengajar di Masjid al-Burhan di proyek Pasar Rumput Jakarta Selatan. Pengajarannya sebagaimana Abdurrahman seorang pengajar di Masjid Asy-Syifa Rumah Sakit Cipto Mangunkusumo. Di antara ajarannya sebagai berikut:

a. Tidak ada adzan dan iqamat pada saat akan melaknasankan salat wajib

b. Seluruh salat masing-masing hanya dikerjakan dua rakaat.

c. Puasa Ramadhan hanya dilaksanakan bagi yang melihat bulan saja berdasarkan QS. Al-Baqarah/2: 185. “ Karena itu barang siapa di antara kamu hadir ( di negeri tempat tinggalnya) di bulan itu, maka hendaklah ia berpuasa pada bulan itu". Mereka memahami ayat ini bahwa yang wajib berpuasa adalah yang melihat bulan saja, bagi yang tidak melihatnya tidak diwajibkan berpuasa, akhirnyua mereka tidak ada yang berpuasa karena mereka tidak melihatnya. ${ }^{12}$

Paham Ingkar Sunah yang dikembangkan oleh Abdurrahman dan pengikut-pengikutnya dan buku tulisan Moch. Ircham Sutarto akhirnya dilarang beredar Jaksa Agung RI Keputusan No: KEP-169/J.A/9/1983 yang ditanda tangani oleh Ismail Saleh, SH dengan alasan keresahan masyarakat, mengganggu keamanan dan ketertiban umum, merusak kerukunan internal umat beragama dan menggoyahkan persatuan. Demikain juga Keputusan Komisi Fatwa MUI 27 Juni 1983 M/ 16 Ramadhan 1403 H yang memutuskan kesesesatan Ingkar Sunah.

Setahun kemudian Jakasa Agung RI mengeluarkan keputusannya dengan Nomor: KEP-059/J.A/3/1984 yang melarang peredaran kaset suara hasil produksi PT. Ghalia Indonesia Recording yang memuat ajaran Ingkar Sunah.

\section{Dalimi Lubis dan Nazwar Syamsu}

Dalimi Lubis salah seorang oknum karyawan Kantor Departemen Agama Padang Panjang, lulusan IKIP Muhammadiyah Padang. Menurut M 
Djamaluddin (tokoh pemberantasan Ingkar Sunah Indonesia) dialah pimpinan gerakan Ingkar Sunah Sumatra Barat. Penyebaran paham Ingkar Sunah dilakukan melalui tulisan-tulisannya baik dalam bentuk artikel maupun buku dan kaset rekaman ceramahnya yang direproduksi oleh PT Ghalia Indonesia. Di antara tulisan artikel Dalimi Lubis tentang penghujatan terhadap perawi Hadis Abu Hurairah dimuat di Suara Muhammadiyah No. 05/80/1995. ${ }^{13}$ Judul buku-buku karyanya antara lain; Alam Barzah dan Adapun Hukum dalam Islam Hanya al-Qur'an Saja.

Nazwar Syamsu seirama dengan Dalimi Lubis lebih banyak menulis beberapa buku berpaham Ingkar Sunah dan ceramah melalui kaset. Ada 14 judul lebih buku dan ceramahnya yang dicetak dan direproduksi PT Ghalia Indonesia sebagaimana yang tertera dalam Keputusan Jaksa Agung dan judul-judul lain yaitu; Isa dan Venus al-Qur'an dan Benda Angkasa, alQur'an dan Sejarah Manusia (Penerbit Pustaka Sa'diyah Padang Panjang), Haji dari Segi Geologi dan Sosiologi. ${ }^{14}$

Bahkan menurut Koran Terbit terdiri 23 judul kaset yang mendapat rekomendasi dari Depag RI No. ND/314/83 antara lain Menghayati Hukum Agama, Mematuhi Hukum Allah, Iman dan Islam, Akhirat, Hal Mati dan Siksa Kubur, Asala Muasal Manusia, Isa al-Masih dan Antar Planet, Adam dan Antar Planet, dan lain-lain. ${ }^{15}$ Isi Kaset yang berjudul Mematuhi Hukum Allah dan kaset lain antara lain:

a. Hadis yang palsu dan dipalsukan. Sebagian besar hadis itu palsu dan dipalsukan maka timbullah pertentangan atau khilafiah di antara masyarakat Islam. Dalam hal ini Yahudi berhasil tipu muslihatnya.

b. Ahlussunah Wal Jamaah hanya penamaan saja, orang-orang Islam kini tidak dapat data pasti tentang mereka. Mengikuti mereka berarti membenarkan khilafiyah. Ahlussunah yang dimaksud empat madzhab Syafi'i, Hanbali, Maliki dan Hanafi, berdasarkan Hadis Nabi ini gagal menjadi dasar hukum Islam. ${ }^{16}$

c. Manusia pertama bukan laki-laki dan bukan Adam melainkan seorang wanita yang tidak diketahui namanya. Manusia pertama itu tidak dijadikan dari tanah melainkan dari meteor, kemudian ia melahirkan seorang anak laki-laki dan kemudian kawin dengan anaknya itu. Mereka berdiam di planet Muntaha dan berkembang biak di sana, sehinghga suatu saat Tuhan memindahkan sepasang dari mereka ke bumi ini dan seterusnya. ${ }^{17}$

Nazwar Syamsu juga telah menerjemahkan ayat-ayat al-Qur'an 30 juz yang menyesatkan. Di antara contoh sebagaimana yang dikutip M Amin Djamaluddin, adalah sebagai berikut: 
a. QS. Al-Baqarah/2: 63:

"Kami angkatkan aurora di atasmu" (Aurora seperti pelangi atau benda terbang mengkilap produksi Israil)

b. QS. Ali Imran/3: 136:

"Dan surga-surga yang bergerak siang-siang di bawahnya".

c. QS. Ali Imran/3: 181

"Serta pembunuhan mereka atas pengkabaran-pengkabaran tanpa hal logis"

Dan masih banyak ayat-ayat atau kalimat yang ditafsirkan secara menyimpang dengan menggunakan logika belaka semata tidak menggunakan penafsiran yang mu'tamad sebagaimana yang ditafsirkan oleh para ulama.

Akhirnaya Jaksa Agung RI mengeluaran Keputusannya dengan Nomor: KEP-085/J.A/9/1985 yang melarang peredaran barang-barang cetakan/buku-buku karangan dan rekaman kaset-kaset suara susunan Nazwar Syamsu dan Dalimi Lubis yang ditanda tangani oleh Jaksa Agung Ari Suharto, SH. Judul buku-buku dan rekaman kase suara susunan Nazwar Syamsu dan Dalimi Lubis yang tertera dalam keputusan ini sebagai berikut:

a. Terjemahan (Tafsir) al-Qur'an Jilid I dan II

b. Tauhid \& Logika, al-Qur'an tentang Manusia dan Masyarakat

c. Tauhid \& Logika, Manusia dan Ekonomi

d. Tauhid \& Logika, al-Qur'an tentang al-Insan

e. Tauhid \& Logika, al-Qur'an tentang Mekkah dan Ibadah haji

f. Tauhid \& Logika, al-Qur'an tentang Shalat, Puasa dan Waktu

g. Tauhid \& Logika, al-Qur'an Dasar Tanya Jawab Ilmiah

h. Tauhid \& Logika, al-Qur'an tentang Pelengkap al-Qur'an Dasar Tanya Jawab Ilmiah

i. Tauhid \& Logika, al-Qur'an dan Sejarah Manusia

j. Tauhid \& Logika, Perbandingan Agama (al-Qur'an dan Bibel)

k. Kamus al-Qur'an (Diktionari)

1. Koreksi terjemahan al-Qur'an Bacaan Mulia HB. Yasin karangan Nazwar Syamsu, dan

m. Alam Barzah(Alam Kubur) karangan Dalimi Lubis

Keputusan Jaksa Agung mewajibkan kepada yang menyimpan, memiliki, mengumumkan, menyampaikan, menyebarkan, mengedarkan, 
memperdagangkan dan mencetak kembali barang-barang cetakan/bukubuku dan atau kaset-kaset suara tersebut untuk menyerahkan kepada Kejaksaan Negeri/ Kejaksaan Tinggi setempat. Sekalipun sudah ada keputusan Pemerintah RI untuk melarang peredaran buku-buku tersebut atau kaset-kaset rekaman ceramah tersebut tidak menghentikan kegiatan mereka pada tahun 1986 berikut nanti di Tegal Jawa Tengah masih cokol muncul kembali yang dipimpin oleh As'ad bin Ali Baisa dan 1988 di Bogor dipimpin oleh H. Endi Suhardi.

\section{As'ad bin Ali Baisa}

As'ad bin Ali Baisa berusia sekitar 60 tahun pada tahun 1986 tinggal di Jalan Delima Desa Pepedan komplek Masjid Nurul Huda Kec. Dukuhturi Tegal Jawa Tengah. Asal orang ini berketurunan Arab asli dan pernah mendapat pendidikan agama di sejumlah sekolah Islam di Indonesia. Dia telah memiliki kader dan pengikut sebanyak 20 orang. Kelompok ini juga mempunyai organisasi pengurus penyebaran ajaran dengan nama ISC (Islamic Study Club). Kegiatan ajaran agama yang dikembangkan cukup meresahkan masyarakat Tegal sekitarnya setelah mereka dengan berani menyatakan diri ingkar terhadap Sunah-Sunah Nabi Muhammad saw dan hanya berpegang kepada al-Qur'an saja.

Di antara ajarannya ialah sebagai berikut:

a. Shalat Jum'at harus dikerjakan 4 rakaat

b. Bagi yang terpaksa berbuka pada bulan suci Ramadhan karena sakit atau bepergian tidak perlu menggantinya. Sedangkan bagi wanita yang haid harus melakukan shalat.

c. Hadis Bukhari Muslim suatu Hadis yang bidayatul mujtahid (mujtahid pemula). Isinya banyak yang bertentangan dengan alQur'an dan merekalah sebagai pemecah umat Islam.

d. Orang yang habis mengambil air wudu jika terkencing dan buang angin tidak perlu repot-repot mengulangi wudunya, bisa terus shalat saja

e. Mi'raj Nabi hanyalah dongeng dan khayalan saja. ${ }^{18}$

\section{H. Endi Suradi}

H. Endi Suradi tinggal di Kamp. Panca Marga Dermaga Bogor Jawa Barat. Pekerjaannya sebagai seorang guru yang dan Pimpinan aliran Ingkar Sunah. Aliran sesat ini sudah dimulai sejak 1981. Pengajiannya diselenggarakan setiap hari Minggu yang dihadiri terdiri dari kaum pria dan wanita dengan berbagai tingkat golongan usia. Mula pertama menurut utusan yang 
menyamar menjadi pengikut, $\mathrm{H}$. Endi mempunyai pengikut sekitar 80 orang terdiri dari 40 pria tua dan muda, 30 wanita tua dan muda dan 10 orang anak-anak. Materi pengajiannya yang dibahas al-Qur'an dengan metode ceramah. Al-Qur'an ditafsirkan menurut faham logika sendiri sepotongsepotong. Dalam menerangkan arti ayat-ayat al-Qur'an hanya berdasarkan pemahaman sendiri dalam arti tidak mau mengikuti kaedah-kaedah yang berlaku umum bagi umat Islam. Nampaknya dalam pemahaman ayat-ayat al-Qur'an masih bersifat tebak-tebakan atau karena dia sendiri bukan seorang yang faham dan mengerti bahasa Arab dan agama. ${ }^{19}$

Ajarannya membuat keresahan umat Islam. Koordinator Pemberantasan Aliran Ingkar Sunah Indonesia M Amin Djamaluddin di Jakarta bekerja sama dengan BKSPP (Badan Kerja sama Podok Pesantren) Jawa Barat KH. Soleh Iskandar yang telah lama memantau aliran ini melapor dan minta pertanggung jawaban Pemerintah untuk menghentikan dan melarang kegiatan aliran tersebut melalui Departemen Agama dan MUI Bogor.

Di antara ajarannya sebagai berikut:

a. Semua shalat lima waktu hanya dilakukan dua rakaat dan sujudnya dalam setiap rakaat hanya dilakukan satu kali sujudan dengan alasan mengikuti shalatnya Nabi Ibrahim.

b. Nabi Muhammadpun shalatnya mengikuti cara Nabi Ibrahim dengan berpedoman pada dalil al-Qur'an Surah al-Nisa/4: 101-103

c. Rukun Islam lima tidak berfungsi apa-apa yang penting adalah pemahaman al-Qur'an, karena al-Qur'an mencakup segalanya.

d. Syahadat tidak perlu diucapkan yang penting adalah pemahaman alQur'an, dengan memahami al-Qur'an seseorang dianggap muslim. Demikian juga shalat diwajibkan bagi yang paham al-Qur'an, bagi yang tidak paham al-Qur'an tidak wajib shalat. ${ }^{20}$

Demikian pikiran para Pengingkar Sunah di Indonesia yang pada umumnya menolak Sunah secara keseluruhan.

Secara umum pokok-pokok ajaran Ingkar Sunah Indonesia antara lain dapat disebutkan sebagai berikut:

1. Tidak mengakui dua kalimat syahadat

2. Tidak mengakui shalat 5 waktu dan adzan iqamat setiap waktu

3. Tidak mengakui adanya shalat Idul Fithri, Idul Adha dan shalat terawih

4. Menghilangkan shalat berjamaah setiap waktu

5. Tidak ada kewajiban puasa Ramadhan, zakat fithrah dan shalat Jum'at 
6. Orang mati tidak boleh dimandikan, dikafankan dan dishalatkan

7. Allah dan Rasul manunggal (dwi tunggal) mengikuti Hadis Nabi haram

8. Nabi Muhammad tidak berhak menerangkan agama yang membinasakan umat. ${ }^{21}$

9. Dan lain-lain.

\section{ANALISIS PEMIKIRAN INGKAR SUNAH}

Analisis pemahaman dan pemikiran Ingkar Sunah akan difokuskan pada pokok-pokok pikiran yang penting saja mengingat banyaknya pemikiran tetapi dapat disimpulkan intinya adalah Islam hanyalah al-Qur'an, Nabi tidak berhak menjelaskan al-Qur'an dan Hadis-hadis yang beredar ini palsu. Analisis akan difakuskan pada tiga hal ini:

\section{Islam hanyalah al-Qur'an}

Islam memang dapat dikatakan hanyalah al-Qur'an karena kesempurnaan kandungannya. Al-Qur'an mengandung segala sesuatu, tetapi keterangannya secara global dan yang pokok-pokok saja. Sedang penjelasan secara terperinci adanya dalam Hadis. Penjelasan Sunah tidak berarti mengurangi kesempurnaan al-Qur'an sedikitpun, justru menambah dan memperkokoh kesempurnaannya.

Sesuatu hal yang tidak dapat diingkari oleh akal sehat adalah keintegrasian Sunah kedalam al-Qur'an, karena yang memberikan informasi bahwa ini kalam Allah adalah perkataan Nabi saw yang disebut dengan Sunah. Jikalau perkataan Rasul ini tidak dapat dijadikan hujah, maka tidak mungkin terealisasi kemukjizatan al-Qur'an. Demikian juga dalam mengetahui rincian jumlah rakaat salat fardu, ukuran minimal wajib zakat $($ nis\} $a>b$ ) dan lain-lain, tanpa Sunah sulit memahami dan melaksanakan kandungan al-Qur'an. Dengan demikian kehujahan Sunah adalah merupakan keharusan dalam agama (d;aru>ri $>$ yah di $>$ ni $>$ yah $)$.

Al-Qur'an perintah mengikuti Nabi, banyak ayat-ayat yang menunjukkan hal itu, misalnya QS. al-H asyr/59: 7

Apa yang diberikan Rasul kepadamu maka terimalah dia. Dan apa yang dilarangnya bagimu maka tinggalkanlah

Bagaimana cara mengikuti Nabi? Tentunya dengan mempelajari Sunah dan mengamalkannya. Jika seseorang konsisten mengamalkan alQur'an berarti ia mengamalkan Sunah. Sunah Nabi sebagai sumber hukum Islam setelah al-Qur'an dan selalu berintegrasi dengan al-Qur'an. Beragama 
tidak mungkin bisa sempurna tanpa Sunah, sebagaimana syariat tidak mungkin sempurna tanpa didasarkan kepada Sunah. Para sahabat menerima langsung penjelasan Nabi tentang syariat yang terkandung dalam alQur'an baik dengan perkataan, perbuatan dan ketetapan beliau yang disebut dengan Sunah itu. Demikian juga umat Islam setelahnya, tidak mungkin dapat memahami hakekat al-Qur'an, kecuali harus kembali kepada Sunah.

Oleh karena itu umat Islam dahulu dan sekarang sepakat (kecuali kelompok minoritas), bahwa Sunah Rasul baik berupa perkataan, perbuatan, dan pengakuannya sebagai salah satu sumber hukum Islam dan seseorang tidak bisa melepaskan Sunah untuk mengetahui halal dan haram.

Memahami al-Qur'an yang benar tentunya diperlukan penguasaan bahasa Arab dan tata bahasa Arab yang baik, tidak asal bunyi dan tidak asal diartikan menurut logikanya sendiri. Jika diperhatikan pemikiran Ingkar Sunah di atas ditemukan berbagai kekacauan dalam memahami Islam, baik dari segi terjemahan teks al-Qur'an, pemahaman dalil teks, kontekstualitas ayat maupun dari segi konsistensinya. Hal ini menunjukkan bahwa mereka tidak memahami bahasa Arab dan tata bahasa Arab, tidak paham Ulumul Qur'an, Asbab al-Nuzul dan ilmu-ilmu lain sebagai perangkat pemahaman ayat-ayat al-Qur'an dan penafsirannya. Misalnya beberapa ayat berikut ini:

a. Penerjemahan QS. QS Ali Imran/3: 128:

"Tidaklah ada (haq) wewenang bagi kamu tentang urusan (perintah) sedikitpun".

Terjemahan M Ircham Sutarto di atas menggambarkan bahwa ia memahami al-Qur'an hanya sepotong-potong tidak melihat kontek kalimat sesudah dan sebelumnya. Mari kita lihat ayat sebelum dan sesudahnya ayat: 127-128.

(Allah menolong kamu dalam perang Badar dan memberi bantuan itu) untuk membinasakan segolongan orang-orang yang kafir, atau untuk menjadikan mereka hina, lalu mereka kembali dengan tiada memperoleh apa-apa. Tak ada sedikitpun campur tanganmu dalam urusan mereka itu atau Allah menerima taubat mereka, atau mengazab mereka, karena sesungguhnya mereka itu orang-orang yang zalim.

Konteks ayat berkaitan dengan urusan orang-orang kafir yakni Nabi tidak ada urusan dengan mereka orang-orang kafir bukan berkaitan dengan perintah Allah. Pemaknaan ayat hendaknya dikaitkan dengan kalimat sebelum dan sesudahnya, sebagaimana disebutkan sebelumnya kata; الَّذِينَ كَفَرُوا dan disebutkan pula setrelanya dhamir

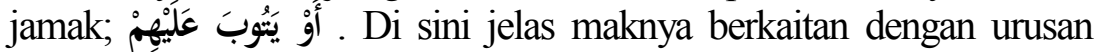


orang kafir, bukan berkaitan dengan perintah Allah. Terjemahan Ircham Sutanto kelas terjadi penyimpangan pemahaman yang ingin memisahkan antara Nabi dari Tuhan aatu antara Hadis dengan alQur'an.

b. Terjemahan QS. QS. Al-Baqarah/2: 198 yang dipahami Muhammad saw telah tersesat sebelum mendapat wahyu:

Dan ingatlah kepadanya seperti yang telah kami tunjukkan kepadamu dan sesungguhnya kamu (Muhammad) sebelumnya benar-benar orang tersesat.

Pada ayat di atas jelas menggunakan khit $a>b$ d; $a m i>r$ jama' yakni kamu orang banyak (Nabi dan para sahabat yang sedang melaksanakan ibadah haji) bukan hanya Nabi Muhammad. Memang Nabi Muhammad bagian dari mereka dan Nabipun tidak mengetahui cara-cara ibadah haji dan syariah Islamiyah sebelum ada petunjuk wahyu dari Allah. Sebagaimana pula dalam QS. al-Dhuha/93: 7

Dan Dia mendapatimu sebagai seorang yang bingung, lalu Dia memberikan petunjuk.

Tetapi bagi Nabi Muhammad makna kata "Dhâll" di sini tidak mengetahui syariah Islamiyah sebelum mendapat pertunjuk wahyu bukan berarti lawan dari hidayah ${ }^{22}$ seperti kekufuran, kemusyrikan dan kemaksiatan sebagaimana dibuktikan dalam sejaran, bahwa Nabi tidak pernah melakukan hal-hal tersebut.

$\mathrm{Abu}>$ Zahw seorang ulama al-Azhar membagi wahyu menjadi dua bagian yaitu:

1) Wahyu al-matlu>; wahyu yang dibacakan yaitu al-Qur'an yang disampaikan Jibril kepada Nabi saw baik secara lafaz dan maknanya dalam keadaan berjaga.

2) Wahyu gayr al-matlu>; wahyu yang tidak dibacakan yaitu Sunah Nabi saw yang disampaikan Jibril atau lain, baik dalam keadaan berjaga atau tidur. $^{23}$

Baik al-Qur'an maumpun Hadis adalah wahyu dari Allah swt. Nabi tidak mengetahui sesuatu malainkan setelah mendapat wahyu dari Allah. Banyak sekali hadui-hadis yang menjelaskan malaikat Jibril bertemu bengan Nabi dan menyapaikan wahyu selain al-Qur'an yang tidak mungkin diesbutkan pada artikel yang terbatas ini.

c. Terjemahan Nazwan Syamsu . QS. Al-Baqarah/2: 63:

"Kami angkatkan aurora di atasmu" (Aurora seperti pelangi atau benda 
terbang mengkilap produksi Israil)

Kata "rafa'na> fi'il muta'addi maknanya "Kami angkat" bukan Kami agkatkan seperti memuta'adikan fi'il muta'addi. Sedang kata "at\}-t $\}$ u> $r$ " diartikan aurora Auro seperti pelangi atau benda terbang mengkilap produksi Israil. Suatu terjemahan yang aneh dan mengada-ada, terjemahan yang hanya dipahami secara logika sok tahu saint bikinan Israil kalau hal itu benar produksi Israil atau adanya pendekatan dengan Israil.

QS. Ali Imran/3: 136:

"Dan surga-surga yang bergerak siang-siang di bawahnya".

Terjemahan ini menunjukkan ketidak tahuan seorang penterjemah tentang tata bahasa Arab ada fi'il mud\} $a>r i$ ' tidak jelas mana $f a>$ 'il-nya. Ketika al-anha>r diartikan sungai-sungai memang layak menjadi $f a$ ' $i l$ karena ia kata benda, tetapi ketika ia diartikan siangsiang menunjukkan katerangan waktu (z\}araf zaman), hpemaknaan ini juga tidak benar karena ia marfü' tidak mans\}'ub.

QS. Ali Imran/3: 181

"serta pembunuhan mereka atas pengkabaran-pengkabaran tanpa hal logis"

Penyimpangan di sini kata al-anbiya $>$ diartikan pengkhabaran, padahal jelas ia jamak dari kata "Nabiy". Pengkhabaran dalam bahasa Arab $a l-A n b a>$ jamak dari kata Naba > 'bukan al-Anbiya $>$ '.

Terjamahannya hanya sekedar dari pemaknaan bahasa yang sangat minim penguasaannya. Kemampuan mereka dalam berbahasa Arab diragukan. Bagaimana mereka mengaku bahwa Islam hanya al-Qur'an sementara mereka tidak mengetahui bahasa Arab serta tata bahasanya dengaan baik? Bukankah pemahaman mereka akan menghancurkan Islam? Mereka dari kalangan bukan ahli agama dan bukan alumni sekolah agama. Mereka baru tahap mau belajar agama, tetapi sayangnya mereka mengklaim dirinya ahli agama dan secara eksklusif merasa paling benar sendiri sedangkan apa yang dipahami oleh meyoritas umat Islam dipandang suatu kesesatan yang besar.

\section{Nabi Tidak Berhak Menjelaskan al-Qur'an}

Penjelasan Nabi terhadap makna al-Qur'an diperintah al-Qur'an, sebagaimana dijelaskan dalam QS. an-Nahl/16: 44

Dan Kami turunkan kepadamu al-Qur'an, agar kamu menerangkan kepada umat manusia apa yang telah diturunkan kepada mereka supaya mereka memikirkan) 
Ayat ini jelas Allah perintah kepada Nabi untuk menjelaskan makna al-Qur'an kepada manusia, sementara Ingkar Sunah melarangnya, apa maksud pernyataan mereka bahwa Islam hanyalah al-Qur'an. Malah tidak ada sepotong ayat pun yang perintah Ingkar Sunah agar menjelaskan al-Qur'an.

Penjelasan Sunah sangat diperlukan untuk memahami kandungan alQur'an. Nabi seorang penerima wahyu tentunya lebih paham tentang makna kandungan al-Qur'an. Al-Qur'an perintah salat, zakat, puasa haji akan tetapi tidak menjelaskan bagaiman cara melaksanakan semua itu. Bilangan rakaat salat, waktunya, jumlah salat yang diwajibkan, syarat dan rukunnya, salat-salat sunah, dan lain sebagainya dijelaskan Sunah. Demikian juga ibadah dan perintah-perintah lain.

Al-Qur'an menjelaskan segala sesuatu secara global dan dasar-dasarnya baik dalam urusan agama dan dunia. Lantas perinciannya dijelaskan oleh Sunah, sehingga al-Qur'an mampu menjawab segala persoalan yang timbul seiring dengan perkembangan zaman. Penjelasan Sunah terhadap alQur'an tidak mengurangi kesempurnaan kandungan al-Qur'an, justru menunjukkan keunggulan dan kesempurnaan yang mengandung mukjizat.

Semua ulama mengakui adanya hubungan bayan Sunah terhadap alQur'an, tetapi berbeda dalam istilah yang mereka pergunakan. Misalnya Ahl al-Ra'yi berpendapat penjelasan Sunah terhadap al-Qur'an terbagai menjadi 3 hal, yaitu; bayan taqrir (memperkuat), bayan tafsir (menjelaskan yang sulit), dan bayan tabdil atau nasakh (mengganti atau menghapus). ${ }^{24}$ Imam Malik membagi ada 5 bagian, yaiyu: bayan taqrir, bayan tawdih (bayan tafsir), bayan tafs; il (penjelasan terteperinci), bayan basti/bayan ta'wil (keterangan yang panjang lebar), dan bayan tasyri' (menciptakan hukum). ${ }^{25}$ Asy-Sya>fi' i> menetapkan 5 bayan, yaitu; bayan tafs $\}$ il, bayan takhsis ( mengkhususkan), bayan ta' yin (menetapkan satu makna dari dua atau lebih ), bayan tasyri', dan bayan nasakh. Sedangkan Imam Ahmad bin Hanbal dalam hal ini sepaham dengan asy-Syafi'i. Imam Ibn al-Qayyim dalam kitab A lâm al-Muwaqqi în sebagaimana yang dikutip Ash-Shiddieqy menjelaskan pendapat Imam Ahmad, ada 4 penjelasan, yaitu: bayân ta 'kîd, bayân tafsîr, dan bayân tasŷ̀', dan bayân takhshîsh serta bayân taqyîd (memberikan batasan yang mutlak). ${ }^{26}$

Sunah selalu seirama dengan al-Qur'an yang berfungsi sebagai penguat (muakkid), penjelas (mubayyin) dan interpretator (mufassir) ayatayat al-Qur'an yang tersembunyi maknanya, dengan penjelasan yang terperinci dari keterangan ayat-ayat yang global (tafshîl al-mujmal), memberikan batasan keterangan ayat-ayat al-Qur'an yang bebas ( taqyîd almuthlaq), mengkhususkan yang umum (takhshîsh al-âmm), dan menjelaskan hukum yang belum disebutkan dalam al-Qur'an. ${ }^{27}$ Keduanya 
sebagai wahyu yang saling melengkapi antara satu dengan yang lain.

Para ulama sepakat bahwa Nabi bersifat ma shûm. Artinya terjaga dari perbuatan dosa besar dan dari kebohongan dalam menyampaikan risâlah wahyu dengan dalil mukjizat. Demikian juga, Nabi dijaga dari perbuatan yang merendahkan pangkat kenabian, seperti akhlak yang rendah dan lain-lain, dari kesalahan dan lupa menurut pendapat yang shahî $\underline{h}^{28}$

\section{HADIS ATAU SUNAH YANG BEREDAR PALSU}

Sebagian Hadis memang ada yang palsu, tetapi masih banyak Hadis yang shahih bahkan banyak pula Hadis mutawartir. Hadis yang dijadikan hujah atau dasar dalam beragama adalah Hadis shahih dan mutawatir, bukan Hadis palsu. Para ulama ahli Hadis telah meneliti Hadis-hadis yang beredar di berbagai kitab Hadis dan telah ditemukan manaa Hadis yang shahih dan mana yang maudhu'. Hadis maudhu'pun telah dihimpun dalam satu buku sehingga umat mengetahui dan membedakan antara maudhu' dan yang bukan maudhu'.

Keterbelakangan masa kodifikasi Sunah karena perhatian umat Islam awal kepada al-Qur'an yang baru dikodifikasikan pada masa Utsman bin Affan. Sejak awal Sunah juga sangat diperhatikan para sahabat baik melalui praktek dalam kehidupan, penulisan, dan hapalan mereka yang sangat kuat. Tidak ada seorang penelitipun yang menilai Sunah ternodai kepercayaannya pada abad pertama. Kemudian para ulama abad berikutnya telah berusaha dengan sungguh-sungguh dan sangat teliti dalam mengkritik periwayatan baik matan atau sanad-nya sehingga dapat dibedakan mana yang shahîh dan mana yang tidak shahîh $\underline{h}$, untuk dikodifikasikan.

Dalam periwayatan matan Hadis para ulama mempersyaratkan harus disertai dengan sanad $d^{29}$, agar orang tidak berbohong mendengar Hadis dari Rasulillah atau tidak sembarangan meriwayatkan Hadis kecuali diyakini kebenaraannya dari Rasulillah. Sanad ini sangat penting dalam ilmu Hadis, karena Hadis itu terdiri dari dua unsur yang secara integral tak dapat dipisahkan satu dengan yang lain, yakni matan dan sanad. Hadis tidak mungkin terjadi tanpa sanad, karena mayoritas Hadis pada masa Nabi tidak tertulis sebagaimana al-Qur'an dan diterima secara individu (âhâd) tidak secara mutawâtir. Hadis hanya disampaikan dan diriwayatkan secara ingatingatan dan hapalan para sahabat yang andal. Di samping hiruk pikuk para pemalsu Hadis yang tak bertanggung jawab. Oleh karena itu tidak semua Hadis dapat diterima oleh para ulama kecuali telah memenuhi kriteria yang ditetapkan, di antaranya disertai sanad yang dapat dipertangung jawabkan keshahihannya. 
Sanad merupakan salah satu neraca yang menimbang shahih atau dha if-nya suatu Hadis. Andaikata salah seorang dalam sanad ada yang fasik atau yang tertuduh dusta atau jika setiap para pembawa berita dalam mata rantai sanad tidak bertemu langsung (muttashil), dha îf-lah Hadis tersebut sehingga tidak dapat dijadikan hujah. Demikian sebaliknya jika para pembawa Hadis tersebut orang-orang yang cakap dan cukup persyaratan yakni adil, taqwa, tidak fasik, menjaga kehormatan diri (murû'ah), dan memiliki daya ingat yang kredibel, sanadnya bersambung dari satu periwayat kepada periwayat lain sampai kepada sumber berita pertama, maka Hadisnya dinilai shahih.

Studi sanad khusus hanya dimiliki umat Muhammad dalam periwayatan Hadis. Umat dahulu sekalipun dalam penghimpunan kitab suci mereka yang juga tidak ditulis pada masa Nabinya tidak disertai sanad. Pada hal ditulis setelah ratusan tahun dari masa Nabinya. Kitab suci mereka ditulis berdasarkan ingatan beberapa generasi yang dinisbatkan kepada para rasul Nabi Isa yang tidak disertai dengan sanad. Menurut Dr. Maurice Bucaille, (Dalam karangan-karangan yang ditulis pada permulaan sejarah agama Kristen, Injil baru disebutkan lama sesudah surat-surat Paulus. Bukti-bukti tentang adanya Injil baru terdapat pada pertengahan abad II M dan lebih tepat lagi sesudah tahun $140 \mathrm{M})^{30}$

Secara ilmiah periwayatan Hadis lebih otentik dan dapat dipertanggung jawabkan otentisitasnya dilihat dari metodologi penelitian yang mereka gunakan. Sanad adalah sebagai bukti dan sakti atas kebenaran Sunah dari Rasulillah saw.

\section{KESIMPULAN}

Perkembangan Ingkar Sunah Indonesia melebihi batas kewajaran rasionalisasi atau modernisasi pemahaman Hadis, tetapi lebih kepada penolakan Sunah secara hakiki yakni menolak Sunah sebagai dasar beragama secara keseluruhan. Amalan ibadah yang berbau Sunah dan tidak secara eksplisit mereka hilangkan seperti adzan Mereka hanya mengakui al-Qur'an saja dalam beragama, tetapi kurang baik dalam memahami al-Qur'an. Hal ini karena keterbatasan mereka dalam penguasaan bahasa Arab dan tata bahasanya, di samping tidak mengenal ilmu-ilmu dasarnya seperti Ulumul Qur'an atau Ulumut Tafsir, sastra bahasa Arab, Ulumul Hadis dan lain-lain. Tingkatan Ingkar Sunah seperti ini sangat berbahaya dalam beragama, karena petunjuk Hadis dalam memahami al-Qur'an ditolak, sementara kemampuan memahami al-Qur'an sangat minim. Akibatnya, al-Qur'an dipahami dengan semau pendapat mereka sendiri tanpa mengacu kepada 
penjelasan Nabi dalam Hadis atau mengacu kepada kitab-kitab Tafsir yang mu'tabar. Dengan demikian bisa jadi sesungguhnya mereka meninggalkan keduanya yakni al-Qur'an dan hadis atau pemahamannya akan menghancurkan Islam dari dalam.[]

\section{Catatan Akhir:}

${ }^{1}$ Zufran Rahman, Sunnah Nabi SAW Sebagai Sumber Hukum Islam (Jawaban Terhadap Ingkar Sunnah), (Jakarta : CV Pedoman Ilmu Jaya, 1995), h. 162

${ }^{2}$ M Amin Djamaluddin, Bahaya Ingkar Sunah, , h. 64 dan 123 lihat juga Harian Terbit, 6 Juni 1983 dan 13 januari 1988.

${ }^{3}$ M Amin D, Bahaya..., h. 26

${ }^{4}$ Ibid. h. 94 dan Harian Merdeka h. 6, 10 oktober 1986

${ }^{5}$ Hartono Ahmad Jaiz, Aliran dan Paham Sesat di Indonesia, (Jakarta : Pustaka alKautsar, 2004), h. 30

${ }^{6}$ Ibid., h. 30-31

${ }^{7}$ Ahmad Husnan, Gerakan Inkar as-Sunnah dan Jawabannya, (Jakarta: Media Da`wah, 1995), h. 8

${ }^{8}$ Ahmad Chusnan, Gerakan Inkar, h. 9-11

${ }^{9}$ Majalah Tempo, 18 Juni 1983; dan M Amin, Bahaya, h. 66

${ }^{10}$ Hartono, Aliran, h. 29

${ }^{11}$ Majalah Tempo, 18 Juni 1983 dan M Amin, Bahaya, h. 66

${ }^{12}$ Hartono, Aliran, h. 29-30

${ }^{13}$ M Amin D, Bahaya, h. 127-128 dan Pelita, 1 Mei 1995

${ }^{14}$ M. Amin D, Bahaya, h. 84-85 dan terbit 24 Maret 1984

${ }^{15}$ M. Amin D, Bahaya, h. 78-79 dan Terbit, Minggu ke-3 Pebruari 1984

${ }^{16}$ Ibid.

${ }^{17}$ M. Amin, Bahaya, h. 86-87 dan Sinar Pagi, 27 April 1984 Demikian di antara isi kaset Ingkar Sunah menurut keterangan Ketua MUI DKI KH. Abdullah Syafi'i

${ }^{18}$ M Amin D, Bahaya, h. 94 dan Harian Merdeka h. 6, 10 Oktober 1986

${ }^{19}$ M Amin D, Bahaya, h. 123-124 dan Harian Terbit, 13 Januari 1988

${ }^{20}$ Ibid. h. 124

${ }^{21}$ M Amin D, Bahaya, h. 48-69

${ }^{22}$ M Ali as\}-S\}abuni $>$, S affwat at-Tafa $>s i>r, \quad$ (Beirut : Da $>$ r al-Fikr, tth.), juz 3, h. 573

${ }^{23} \mathrm{Abu}>$ Zahw, al-H\{adi>s $\mid$ wa al-Muh\}addis $\mid u>n$, (Beirut : Da $>\mathrm{r}$ al-Fikr, th.), h. 14-15 dan al- Qard\}a>wi>, Kayf Nata $>$ 'a $>$ mal ma'a $>$ as-Sunnah an-Nabawiyah, (Beirut : Da>r al-Fikr, tth.), h. 37

${ }^{24}$ M. Hasbi As-Shiddieqy, Sejarah dan Pengantar Ilmu Hadist, (Jakarta : Bulan Bintang, 1980), h. 179-182

${ }^{25}$ Ibid., h. 183-186 
${ }^{26}$ Ibid., h. 187-188

${ }^{27}$ Lih: QS. an-Nah\}/16: 44; al-Maliki>, al-Manhal al-Lat\}i>f, (Beirut : Da $>\mathrm{r}$ alFikr, tth.), h. 12-15, dan as-Salafi $>$, as-Sunnah $H\{u j j i>y a>t u h a>$, (Beirut : Da $>$ r al-Fikr, tth.), h.97-129

${ }^{28}$ asy-Syawka $>$ ni $>$, Irsya $>d$ al-Fuh $\}$ $>$ l ila $>$ Tah $\} q i>q$ al-H $\{a q$ min Ilmi al$U_{s}\{u>l$, (Beirut: Da $>$ r asy-Sya $<$ 'ab al-'Ilmiyah, 1999), Juz 1, h. 161 dan 162; Abd arRah\}ma>n, as-Sunnah Ga>yah al-Wus\} u>l, h. 31, dan 'Abd al-Kha>liq, H\}ujji>yat, h. 279.

${ }^{29}$ Sanad ; para perawi Hadis secara berantai dari penghimpun sampai kepada Rasulillah. Sedang matan; isi berita yang disadarkan kepada Rasulillah

${ }^{30}$ Maurice Bucaille, Bibel, Qur'an, dan Sains Modern, h. 95

\section{DAFTAR PUSTAKA}

'Abd al-Kha>liq, Hujjiyat as-Sunnah, (Beirut: Dar al-Fikr, tth).

Abd ar-Rah\}man, as-Sunnah Gayah al-Wusul, (Beirut: Dar al-Fikr, tth).

Abu Zahw, al-Hadis wa al-Muhaddisun, (Beirut : Dar al-Fikr, th.),.

As\}-Sabuni, M. Ali, Safwat at-Tafasir, (Beirut: Dar al-Fikr, tth).

As-Shiddieqy, M. Hasbi, Sejarah dan Pengantar Ilmu Hadist, (Jakarta : Bulan Bintang, 1980)

As-Syawkani, Irsyad al-Fuh\}ul ila Tahqiq al-H\{aq min 'Ilmi al-Usul, (Beirut: Dar asy-Sya'ab al-'Ilmiyah, 1999).

Bucaille, Maurice, Bibel, Qur'an, dan Sains Modern, (Jakarta: Bulan Bintang, 2000).

Husnan, Ahmad, Gerakan Inkar as-Sunnah dan Jawabannya, (Jakarta: Media Dakwah, 1995).

Jaiz, Hartono Ahmad, Aliran dan Paham Sesat di Indonesia, (Jakarta : Pustaka al-Kautsar, 2004).

Qardawi, Kayf Nata'amal ma'a as-Sunnah an-Nabawiyah, (Beirut : Dar alFikr, th.).

Rahman, Zufran, Sunnah Nabi SAW Sebagai Sumber Hukum Islam (Jawaban Terhadap Ingkar Sunnah), (Jakarta : CV Pedoman Ilmu Jaya, 1995). 